\title{
Decomposition Rate, pH, and Enamel Color Alteration of At-Home and In-Office Bleaching Agents
}

\author{
Vanessa Cavalli ${ }^{1}$, Bruna Guerra da Silva ${ }^{1}$, Sandrine Bittencourt \\ Berger $^{2}$, Fabiano Carlos Marson ${ }^{3}$, Cinthia Pereira Machado \\ Tabchoury ${ }^{4}$, Marcelo Giannini ${ }^{1}$ (D)
}

'Department of Restorative Dentistry, Piracicaba Dental School, UNICAMP - Universidade Estadual de Campinas, Piracicaba, SP, Brazil ${ }^{2}$ Department of Restorative Dentistry, UNOPAR - Universidade Norte do Paraná, Londrina, PR, Brazil ${ }^{3}$ Dental Press Cursos, Maringá, PR, Brasil

${ }^{4}$ Department of Physiological Sciences, UNICAMP - Universidade Estadual de Campinas, Piracicaba, SP, Brazil

Correspondence: Vanessa Cavalli, Avenida Limeira, 901, 13414018 Piracicaba, SP, Brasil. Tel: +55-19-2106-5338. e-mail:

\begin{abstract}
This study evaluated the decomposition rate (DR), $\mathrm{pH}$, enamel color alteration $(\Delta \mathrm{E})$ and whiteness index $(\Delta \mathrm{WI})$ promoted by at-home and in-office bleaching. Enamel surface was submitted to $(n=10)$ : at-home $(10 \%, 15 \%, 20 \%$ carbamide peroxide - CP, $6 \%$ hydrogen peroxide -HP) and three 35\% HP agents with light irradiation (LED, laser, and halogen) or no treatment (control). The DR and $\mathrm{pH}$ of agents were measured after $0,2,4,6$ and $8 \mathrm{~h}$ (at-home) or after $5,15,20,30$ and 40 min (in-office). Color parameters $\left(L^{*}, a^{*}, b^{*}, \Delta E, \Delta W I\right)$ were determined at baseline and after bleaching. $\mathrm{DR}, \mathrm{pH}, \mathrm{L}^{*}, \mathrm{a}^{*}, \mathrm{~b}^{*}$ data were analyzed by one-way (at-home) or two-way (in-office) repeated measures ANOVA and Tukey test. $\Delta \mathrm{E}$ and $\Delta \mathrm{WI}$, by one-way (at-home) or two-way (in-office) ANOVA and Tukey test. DR of at-home agents was similar after 6 and $8 \mathrm{~h}(\mathrm{p}>0.05)$, with $\mathrm{pH}$ close to neutral $(6.5$ to $6.9, \mathrm{CP})$ or acid 5.9 (6\% HP). From 4 to $8 \mathrm{~h}, \Delta \mathrm{E}$ was higher for $15 \%$ and $20 \% \mathrm{CP}$ compared with $10 \% \mathrm{CP}$ $(p<0.05)$. After $40 \mathrm{~min}, \mathrm{DR}$ of $35 \% \mathrm{HP}$ agents was similar and all exhibited significant $\Delta \mathrm{E}$ in one application $(p<0.05)$, regardless light irradiation. $\Delta W \mathrm{~W}$ indicated whitening effect with no differences among groups ( $p>0.05$ ). One $35 \% \mathrm{HP}$ showed alkaline $\mathrm{pH}$, and the others, $\mathrm{pH}<5.5$. At-home agents could be applied for $2 \mathrm{~h}(15 \%, 20 \% \mathrm{CP}, 6 \% \mathrm{HP})$ and $4 \mathrm{~h}(10 \%$ $\mathrm{CP}$ ) and the in-office agents, up to $40 \mathrm{~min}$ in one application, without light.
\end{abstract}

cavalli@unicamp.br

Key Words: hydrogen peroxide, hydrogen-ion concentration, color.

\section{Introduction}

The transenamel/dentinal diffusion of hydrogen peroxide (HP) is a concern due to possible damages promoted by bleaching agents on vital pulp tissues (1). Some reports indicate that even low-concentrated HP infiltrates enamel and dentin structures, reaching the pulp chamber (2) and promoting cytotoxic effects to odontoblastic-like cells $(3,4)$. These studies indicate that the cytotoxicity is dependent on the concentration of the HP byproducts that reach the pulp, and even low-concentrated (or at-home) carbamide peroxide (CP) agents could promote intense cytopathology effects, reducing cell viability $(3,4)$. Moreover, the intrapulp concentration of the HP is dependent on dentin permeability (5), pulp and osmotic pressure (6), heat applied as a catalyst (7), quality and thickness of enamel/dentin $(8,9)$, and, finally, time of application (10).

Carbamide peroxide was originally designed to be used overnight (6 to 8 h) (11), however, the application time recommended in literature for low concentrations of $\mathrm{CP}(10-$ $16 \%$ ) varies from one (12) to $4 \mathrm{~h}$ (2). The in-office technique, using high HP concentrations (35-38\%), indicates three consecutive 15-min applications, repeated for up to four appointments, with seven-day intervals. Other in-office products indicate the continuous application of HP for 20 min, but manufacturers do not have scientific backgrounds on the decomposition behavior of HP. Overextending HP application times on enamel could cause alterations on enamel surface (5) and lead to HP transenamel/dentin diffusion, increasing the occurrence of sensitivity (13).

The application of light, such as lasers, light-emitting diodes (LEDs), plasma arc and quartz-tungsten-halogen (OTH) lamps, have been proposed to, catalyze the HP decomposition by theoretically, increase the decomposition rate of oxygen to form oxygen-free radicals (14). This reaction could accelerate bleaching, decrease the clinical application time of whitening agents and possibly, decrease tooth sensitivity $(14,15)$. The authors of an in vivo randomized, split-mouth clinical study observed that using a hybrid light (laser/LED) concomitant with highconcentrated HP agents reduced bleaching sensitivity and promoted similar whitening effect compared with conventional in-office bleaching (15). However, the use of light is still controversial as some authors suggest that lights could increase the intrapulpal temperature and the risk of post-operative sensitivity (14).

As scarce information is available regarding bleaching agent's decomposition on enamel surface, the aim of the present study was to evaluate the decomposition rate of low and high-concentrated bleaching agents and the effects of LED, laser, and halogen lamps in the decomposition of the high-concentrated agents. Additionally, enamel color and $\mathrm{pH}$ were evaluated as the optimal time of 
decomposition should correspond to an effective enamel color alteration, and $\mathrm{pH}$ would indicate the products' safety. The null hypothesis tested were that (I) application times of low-concentrated bleaching agents could follow manufacturer's instructions, (II) the decomposition rate of high-concentrated agents is not influenced by the application of light (LED, laser or halogen) and (III) application times of high-concentrated bleaching agents could follow manufacturer's instructions.

\section{Material and Methods}

\section{Specimen Preparation and Black Tea Staining.}

Figure 1 displays the schematic representation of methodology. One hundred and sixty bovine incisors were collected, stored in $0.1 \%$ thymol solution (Labsynth, Diadema, SP, Brazil) and cleaned of gross debris. Teeth free of defects and with similar color and size were chosen. Prior to the chemical analyses, the bovine teeth were immersed and stained with black tea solution (Matte Leão, São Paulo, SP, Brazil) under agitation for $24 \mathrm{~h}$ (6 sachets; $500 \mathrm{~mL}$ of water). The staining method was adapted from that of Sulieman et al. (16). The crown of the stained teeth was isolated with nail varnish leaving a $16 \mathrm{~mm}^{2}$ area of

\section{Group Division}

The stained bovine teeth (160) were divided into low and high-concentrated bleaching treatments: Bleaching with low-concentrated agents were treated with $(n=10): 10 \% \mathrm{CP}$ (Opalescence, Ultradent, South Jordan, UT, USA); 15\% CP (Opalescence, Ultradent); 20\% CP (Opalescence, Ultradent); 6\% HP (Whiteness Class, FGM, Joinville, PR, Brazil). High concentrations of hydrogen peroxide (HP) agents (35\% HP) were also evaluated (HP Maxx - Whiteness HP Maxx, FGM; HP Blue - Whiteness HP Blue FGM or PO - Pola Office, SDI, Bayswater, Victoria, Australia) and each of these three agents were subdivided into four groups according to the light activation methods $(n=10)$ : LED, laser, halogen lamp or without light activation (Control - C). Table 1 displays the composition and application mode of the bleaching

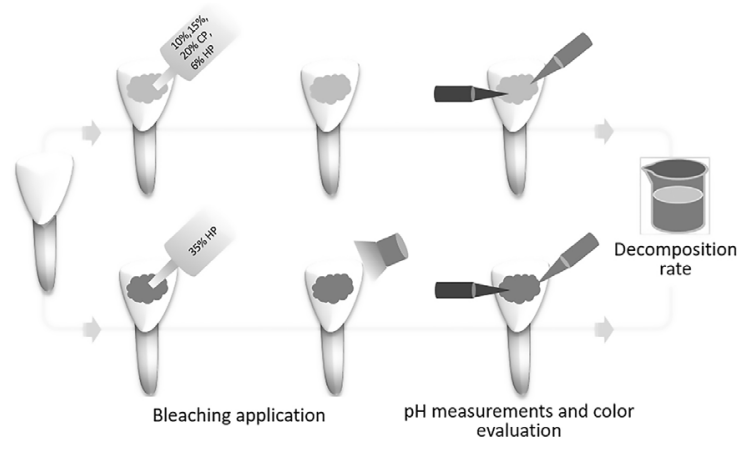

Figure 1. Schematic representation of methodology.

Table 1. Commercial name, composition, manufacturer directions, and experiment application protocol

\begin{tabular}{|c|c|c|c|c|}
\hline Groups & $\begin{array}{l}\text { Commercial name } \\
\text { and manufacturer }\end{array}$ & Composition* & Manufacturer Directions* & $\begin{array}{c}\text { Experimental } \\
\text { application protocol }\end{array}$ \\
\hline $\begin{array}{l}10 \% \mathrm{CP} \\
15 \% \mathrm{CP} \\
20 \% \mathrm{CP}\end{array}$ & $\begin{array}{l}\text { Opalescence } 10 \% \text {, } \\
\text { 15\%, 20\% (Ultradent } \\
\text { Products Inc, South } \\
\text { Jordan, UT, USA) }\end{array}$ & $\begin{array}{l}\text { Carbamide peroxide, glicerin, } \\
\text { carbopol, distilled water, } \\
1100 \text { ppm sodium fluoride }\end{array}$ & Bleaching for $6-8 \mathrm{~h} / \mathrm{d} ; 14-28 \mathrm{~d}$ & One application \\
\hline 6\% HP & $\begin{array}{l}\text { White Class (FGM } \\
\text { Dental products, } \\
\text { Joinville, SC, Brazil) }\end{array}$ & $\begin{array}{l}\text { 6\% HP, neutralized } \\
\text { carbopol, potassium nitrate, } \\
\text { calcium gluconate, sodium } \\
\text { fluoride, distilled water }\end{array}$ & Bleaching for $90 \mathrm{~min} / \mathrm{d} ; 14-28 \mathrm{~d}$. & for $8 \mathrm{~h}$ \\
\hline HP Maxx & $\begin{array}{l}\text { Whiteness HP Maxx } \\
\text { (FGM Dental products, } \\
\text { Joinville, SC, Brazil) }\end{array}$ & $\begin{array}{l}\text { 35\% HP (after mixture), } \\
\text { thickener, pigment, } \\
\text { neutralizing agents, } \\
\text { glycol, distilled water }\end{array}$ & $\begin{array}{l}\text { After mixture, the agent is applied on the } \\
\text { surface for } 15 \text { min and stirred 3-4 times to } \\
\text { promote oxygen release; repeat twice. Light } \\
\text { sources can be used to accelerate bleaching. }\end{array}$ & \\
\hline HP Blue & $\begin{array}{l}\text { Whiteness HP Blue } \\
\text { Calcium (FGM Dental } \\
\text { products, Joinville, } \\
\text { SC, Brazil) }\end{array}$ & $\begin{array}{l}\text { 35\% HP (after mixture), } \\
\text { thickener, violet pigment, } \\
\text { neutralizing agents, } \\
\text { calcium gloconate, } \\
\text { glycol, distilled water. }\end{array}$ & $\begin{array}{l}\text { After mixture, apply on the surface for } 40 \\
\text { min and stir every 5-10 min to promote } \\
\text { oxygen release. Repeat the application up } \\
\text { to } 4 \text { times with a } 7 \text {-d interval. No light } \\
\text { sources needed to accelerate bleaching. }\end{array}$ & $\begin{array}{l}\text { One application } \\
\text { for } 40 \mathrm{~min} .\end{array}$ \\
\hline PO & $\begin{array}{l}\text { Pola Office (SDI, } \\
\text { Southern Dental } \\
\text { Industries, Bayswater, } \\
\text { Victoria, Australia) }\end{array}$ & $\begin{array}{l}\text { 35\% HP and stabilizing } \\
\text { agents; thickener, catalyzing } \\
\text { agent, desensitizers, } \\
\text { blue pigment. }\end{array}$ & $\begin{array}{l}\text { The powder/liquid are mixed (1:4) } \\
\text { and applied on dental surface for } \\
8 \text { to } 20 \text { min and repeated up to } 3 \\
\text { times. Light activation is optional. }\end{array}$ & \\
\hline
\end{tabular}

*MSDS data sheet. 
agents according to the manufacturers. Table 2 presents the light sources, product features, and application protocol.

\section{Bleaching Treatment}

The low-concentrated agents $(10 \%, 15 \%, 20 \% \mathrm{CP}$, and $6 \% \mathrm{HP}$ ) were applied on the buccal surface of the bovine incisors and decomposition rate and $\mathrm{pH}$ were measured immediately ( 0 ) and every two hours until the end of the bleaching treatment $(2,4,6$ and $8 \mathrm{~h})$. Color parameters $\left(L^{*}, a^{*}, b^{*}, \Delta E, \Delta W I\right)$ were measured at baseline and after $8 \mathrm{~h}$ of bleaching. Samples were stored over sterile cotton gauze soaked with distilled water at $37{ }^{\circ} \mathrm{C}$ throughout the bleaching treatment. The decomposition rate and $\mathrm{pH}$ of the $35 \% \mathrm{HP}$ agents were evaluated at $0,5,10,20,30$, and 40 min throughout the bleaching treatment, at room temperature $\left(20{ }^{\circ} \mathrm{C}\right)$ to simulate the in-office technique. Color parameters $\left(L^{*}, a^{*}, b^{*}, \Delta E, \Delta W I\right)$ were measured at baseline and after $40 \mathrm{~min}$ of bleaching. The flowchart (Fig. 2) exhibits the group division and the time line of the evaluations.

\section{Decomposition of Bleaching Agents}

A known amount of the bleaching agent $(0.25 \mathrm{~g})$ was applied on the enamel, and at each evaluation, an aliquot was collected, weighed $(0.01 \mathrm{~g})$ and diluted in $10 \mathrm{~mL}$ of water. The diluted bleaching was added to concentrate sulfuric acid $(20 \mathrm{~mL})$. The concentration of hydrogen peroxide in this solution was determined by titration with $0.1 \mathrm{~N}$ potassium permanganate. This method is based on a reduction-oxidation reaction and quantifies the amount of hydrogen peroxide in the solution (17). Potassium permanganate $\left(\mathrm{KMnO}_{4}: 0.2 \mathrm{~g}\right.$ of $\mathrm{Na}_{2} \mathrm{C}_{2} \mathrm{O}_{4}+250 \mathrm{~mL}$ of $\mathrm{H}_{2} \mathrm{O}+$ $15 \mathrm{~mL}$ of $\mathrm{H}_{2} \mathrm{SO}_{4}$ ) was added to the diluted bleaching agent at a rate of $0.1 \mathrm{~mL} / \mathrm{s}$ until a violet color was observed. The color change corresponds to the equivalence point, when all the $\mathrm{H}_{2} \mathrm{O}_{2}$ had been consumed. The known amount of $\mathrm{KM}_{\mathrm{n}} \mathrm{O}_{4}$ and the known amount of the bleaching agent were applied to the formula: $\mathrm{C}=\mathrm{VxCfx} 1,701 \times 100 / \mathrm{mg}$ (Where: $\mathrm{C}=\mathrm{H}_{2} \mathrm{O}_{2}$ concentration (w/w); $\mathrm{V}=$ volume of $\mathrm{KMnO}_{4}$ added during titration; $\mathrm{Cf}=$ correction factor for the $0.1 \mathrm{~N}$ potassium permanganate solution; and $\mathrm{m}=$ mass of the bleaching product in milligrams) (17). Titration was performed at the intervals $0,2,4,6$, and $8 \mathrm{~h}$ of bleaching with low-concentrated agents, and at $0,5,10,20,30$, and $40 \mathrm{~min}$ of bleaching with high-concentrated agents.

\section{Color Evaluation and pH Measurement}

Simultaneously with the decomposition evaluations, $\mathrm{pH}$ of the bleaching agent was determined and color parameters $\left(L^{*}, a^{*}\right.$, $\left.b^{*}\right)$ were measured at baseline and after bleaching. Prior to the color evaluation, the bleaching material was removed with a resin composite instrument $(8 \mathrm{AL}$,

Fig. 2 Flowchart of the group division and the time line of decomposition rate, $\Delta \mathrm{E}$, $\Delta \mathrm{W}$ and $\mathrm{pH}$ evaluations.

Table 2. Light sources, product features, and application protocol

\begin{tabular}{|c|c|c|c|}
\hline Light sources & Commercial names & Characteristics & Application protocol \\
\hline LED & $\begin{array}{l}\text { Valo (Ultradent } \\
\text { Products Inc, South } \\
\text { Jordan, UT, USA) }\end{array}$ & $\begin{array}{l}\text { Wavelength: } 395-480 \mathrm{~nm} \text {. Light } \\
\text { intensity: } 790 \mathrm{~mW} / \mathrm{cm}^{2} \text {. }\end{array}$ & $\begin{array}{l}\text { The bleaching gel remains } 1 \text { min without } \\
\text { agitation and is light irradiated for } 2 \text { min. } \\
\text { The procedure must be repeated } 3 \text { times with } \\
\text { 1-min interval among irradiations. }\end{array}$ \\
\hline Laser diode & $\begin{array}{l}\text { Whitening Lase Light } \\
\text { Plus (DMC Equipment, } \\
\text { São Carlos,SP, Brazil) }\end{array}$ & $\begin{array}{l}\text { LED wavelength: } 470 \mathrm{~nm} \text {. Infrared } \\
\text { diode laser wave length (3): } \\
810 \mathrm{~nm} \text { and power of } 0.2 \mathrm{~W} \text {. }\end{array}$ & $\begin{array}{l}\text { The bleaching gel remains } 1 \text { min on surface } \\
\text { without agitation and is light irradiated for } 2 \\
\text { min. The procedure can be repeated } 3 \text { times } \\
\text { with 1-min interval among irradiations. }\end{array}$ \\
\hline Halogen & $\begin{array}{l}\text { Optilux } 501 \text { (Demetron/ } \\
\text { Kerr, Danbury, CT, USA) }\end{array}$ & $\begin{array}{l}\text { Wavelength: } 560 \mathrm{~nm} \text {. Light } \\
\text { intensity: } 600-800 \mathrm{~mW} / \mathrm{cm}^{2} .\end{array}$ & $\begin{array}{l}\text { The bleaching agent is applied on the surface } \\
\text { for } 2 \text { min and irradiated for } 30 \mathrm{~s} \text {. The irradiation } \\
\text { is repeated } 3 \text { times with a } 2 \text {-min interval. }\end{array}$ \\
\hline
\end{tabular}

MSDS data sheet. 
Cosmedent Restorative Dental Products, Chicago, IL, USA) and the enamel surface was cleaned with distilled water and air dried. The same gel that was removed was reapplied after color measurements. Color evaluation was determined with a spectrophotometer (Vita Easyshade Advance, VITA Zahnfabrik H. Rauter GmbH \& Co. KG, Bad Sackingen, Germany) and the tip of the device was placed perpendicularly, in contact with the exposed enamel area. A silicon mold matrix was used to standardize the position of the tip. In each evaluation, three measurements were recorded according to the color parameters $L^{*}, a^{*}$, and $b^{*}$, of the CIE Lab (Commission Internationale de I'Eclairage, $\left.L^{*}, a^{*}, b^{*}\right)$ system. The CIE color $L^{*}$ parameter corresponds to the value or degree or lightness, whereas $a^{*}$ and $b^{*}$ co-ordinates designate positions on red/green $\left(+a^{*}=\right.$ red, $-a^{*}=$ green $)$ and yellow/blue $\left(+b^{*}=\right.$ yellow $-b^{*}=$ blue $)$ axes. The color parameters were averaged and color differences $(\Delta E)$ calculated using the following equation at each interval: $\Delta \mathrm{E}=\left[\left(\Delta \mathrm{L}^{*}\right)^{2}+\left(\Delta \mathrm{a}^{*}\right)^{2}+\left(\Delta \mathrm{b}^{*}\right)^{2}\right]^{1 / 2}$.

The whiteness index for Dentistry was calculated using the $L^{*}, a^{*}, b^{*}$ parameters of transmittance analysis, according to the equation: $\mathrm{WI}=0.511 \mathrm{~L}^{*}-2.3424 \mathrm{a}^{*}-1.100 \mathrm{~b}^{*}$ (18), in which, higher WI values indicate whiter samples and lower WI (including negative values), indicate darker samples. According to this index, the whiter the material, the higher and more constant is the reflectance across the visible wavelength range (near to $100 \%$ of reflectance value of 1) (18). The baseline and final (after bleaching) whiteness index was calculated according to: $\Delta \mathrm{WI}=\mathrm{WI}_{\text {after }}$ bleaching $-W I_{\text {baseline. }}$

The $\mathrm{pH}$ of bleaching agents was measured throughout the bleaching treatment at the intervals previously established, with a potentiometer (Equilam, Diadema, SP, Brazil) previously calibrated with buffered solutions $(\mathrm{pH}$ 4.0 and $\mathrm{pH}$ 7.0).

\section{Statistical Analysis}

Data was submitted to exploratory analysis using SAS software (Realease 9.1, SAS Institute, Cary, NC, USA). The mean values were submitted to one-way (at-home bleaching agents) or two-way (in-office agents and light activation) repeated measures ANOVA followed by the Tukey test, at a $5 \%$ level of confidence, for the variable responses decomposition rate and $\mathrm{pH}, \mathrm{L}^{*}, \mathrm{a}^{*}$ and $\mathrm{b}^{*}$. Color alteration $(\Delta \mathrm{E})$ and whiteness index $(\Delta \mathrm{WI})$ were evaluated by one-way (at-home bleaching agents) and two-way (in-office agents and light activation) ANOVA, followed by the Tukey test $(\alpha=0.05)$.

\section{Results}

Decomposition of Low-Concentrated Bleaching Agents.

From 0 to $4 \mathrm{~h}$ groups presented different HP concentrations, according to their initial HP amount. However, after 6 and $8 \mathrm{~h}$ no differences were detected among the groups $(p>0.05)$. The HP percentage of $10 \%$ $\mathrm{CP}$ decreased after $4 \mathrm{~h}$ and remained constant up to 8 h. The HP amount of 15\% CP decreased after 2 and $8 \mathrm{~h}$, whereas for 20\% CP the concentration declined after 2, 4 and $6 \mathrm{~h}$ and no statistical differences were observed in the decomposition rate from 6 to $8 \mathrm{~h}$ of bleaching $(\mathrm{p}>0.05)$. The HP concentration of $6 \% \mathrm{HP}$ decreased after 2 and $4 \mathrm{~h}$ and remained until $8 \mathrm{~h}$ of bleaching. Figure 3 displays the decomposition rate of the low-concentrated agents as a function of time.

\section{Decomposition of High-Concentrated Bleaching Agents}

The HP rate of HP Maxx decreased after 5 min of bleaching regardless of light activation, and after $40 \mathrm{~min}$ no differences were observed among HP Maxx groups regardless light activation. The decomposition of HP Blue without light activation (C) significantly decreased only after 30 min of bleaching. Contrarily, LED, laser, and halogen lamp hastened the decomposition rate, as it was significant after 5, 10, and 20 min of bleaching, respectively. After 40 $\mathrm{min}$, the HP rate was lower in the HP Blue laser and halogen lamp than in the LED and C groups. Decomposition of PO was observed after $5 \mathrm{~min}$ of the LED and laser groups and after $10 \mathrm{~min}$ for the halogen and $\mathrm{C}$ groups. After $40 \mathrm{~min}$ of bleaching, no differences were observed among the PO decomposition rates (regardless of light activation). The average decomposition of the high-concentrated agents was $15 \%$. Consequently, most groups reached a final average concentration of 20\% HP. Figure 4 displays the decomposition rates of the high-concentrated agents as a function of time and light activated methods.

\section{Color Alteration of Low-Concentrated Bleaching Agents}

At baseline, bleaching agents exhibited similar $L^{*}, a^{*}, b^{*}$ (Table 3 ). After $8 \mathrm{~h}$ of bleaching, lightness $\left(\mathrm{L}^{*}\right)$ increased,

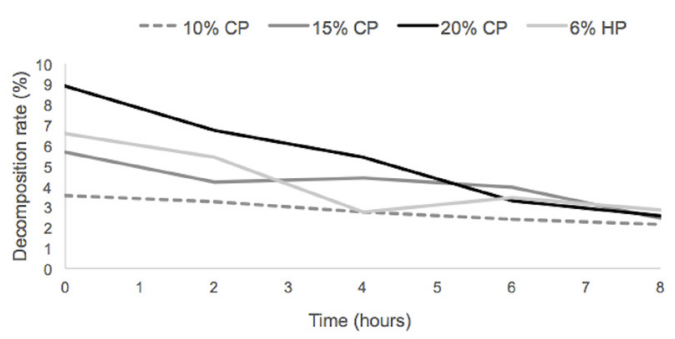

Figure. 3 Decomposition rate of hydrogen peroxide (\%) of 10\% CP, $15 \% \mathrm{CP}, 20 \% \mathrm{CP}$, and $6 \% \mathrm{HP}$ as a function of time. 
$b^{*}$ (yellow-blue) values decreased and $a^{*}$ (red-green) values decreased for 15\% CP and 20\% CP groups. In the first 2 $\mathrm{h}, \Delta \mathrm{E}$ was similar among groups ( $\mathrm{p}>0.05$ ) (Table 4). The $\Delta \mathrm{E}$ values of $20 \% \mathrm{CP}$ at the time points $4 \mathrm{~h}-2 \mathrm{~h}, 6 \mathrm{~h}-4 \mathrm{~h}, 8 \mathrm{~h}$ $-6 \mathrm{~h}$ and $8 \mathrm{~h}$ - Baseline were greater than that of $10 \% \mathrm{CP}$ $(p<0.05)$ and similar to $6 \% \mathrm{HP}$ and $15 \%$ CP (Table 4). $\Delta \mathrm{WI}$ exhibited positive values and no differences were detected in the whiteness index among groups ( $p>0.05$ ) (Table 4).

\section{Color Alteration of the High-Concentrated Bleaching Agents}

At baseline, bleaching agents exhibited similar $L^{*}$, $a^{*}, b^{*}$ (Table 5). After 40 min of bleaching, lightness ( $\left.L^{*}\right)$ increased, $b^{*}$ and $a^{*}$ values decreased. No differences in $\Delta \mathrm{E}$ were detected among bleaching agents at the time points $5 \mathrm{~min}$ - Baseline and $10 \mathrm{~min}-5 \mathrm{~min}$, regardless light activation ( $p>0.05$ ) (Table 6$)$. The use of light associated with HP Maxx (regardless the light source) increased $\Delta \mathrm{E}$ at the interval $40 \mathrm{~min}-30 \mathrm{~min}$ compared to control group. However, no differences were observed in $\triangle \mathrm{E}$ of HP Maxx, HP Blue and PO- treated groups at 40 min - Baseline. $\Delta \mathrm{WI}$ exhibited positive values and no differences were found in the whiteness index among groups, regardless bleaching protocols or light activation modes ( $p>0.05$ ) (Table 6).

\section{pH of Low-Concentrated Bleaching Agents.}

Bleaching agents exhibited different $\mathrm{pH}$ values during evaluations $(\mathrm{p}<0.05)$. The $\mathrm{pH}$ of $10 \%, 15 \%$, and $20 \% \mathrm{CP}$ at the intervals $(0,2,4,6$, and $8 \mathrm{~h})$ were close to 7.0 , while $6 \% \mathrm{HP}$ was lower, ranging from 5.8 to $6.1(\mathrm{p}<0.05)$. No differences were observed for $10 \%, 15 \%$, and $20 \% \mathrm{CP}$ and no significant variation was observed from baseline to $8 \mathrm{~h}$ of treatment for any of the low-concentrated bleaching agents tested ( $p>0.05)$. Figure 5 displays $\mathrm{pH}$ variations of the low-concentrated agents as a function of time.

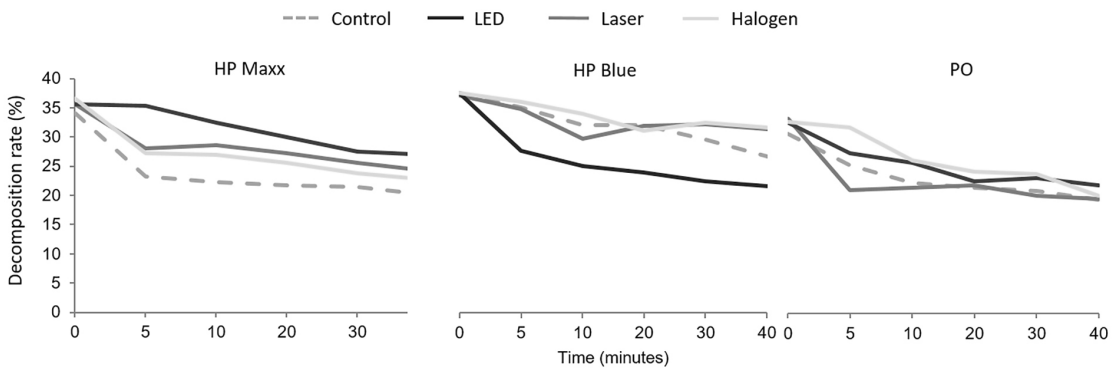

$\mathrm{pH}$ of High-Concentrated Bleaching Agents.

High-concentrated agents exhibited differences in $\mathrm{pH}$ throughout the evaluation $(p<0.00001)$. However, light activation did no change the $\mathrm{pH}$ of such agents ( $\mathrm{p}=0.3496)$. HP Blue demonstrated the greatest $\mathrm{pH}$ values $(8.3-8.5)$

Fig. 4 Decomposition rate (\%) of 35\% HP agents as a function of time and light activation methods.

Table 3. $\mathrm{L}^{*}, \mathrm{a}^{*}, \mathrm{~b}^{*}$ mean values (standard deviation) according to the bleaching agents

\begin{tabular}{|c|c|c|c|c|c|c|c|}
\hline \multirow{3}{*}{$\begin{array}{l}\text { Groups } \\
6 \% \mathrm{HP}\end{array}$} & \multicolumn{2}{|c|}{$\mathrm{L}^{*}$} & \multicolumn{2}{|c|}{$a^{*}$} & \multicolumn{3}{|c|}{$\mathrm{b}^{*}$} \\
\hline & Baseline & After treatment & Baseline & After treatment & Baseline & After trea & \\
\hline & 64.6 (3.6) Aa & $71.8(2.9) \mathrm{Ab}$ & $7.6(1.1) \mathrm{Aa}$ & $5.9(0.7) \mathrm{Aa}$ & 19.3 (1.6) Аa & $15.1(1.5)$ & $\mathrm{Ab}$ \\
\hline $10 \% \mathrm{CP}$ & $65.1(2.2) \mathrm{Aa}$ & $72.4(2.1) \mathrm{Ab}$ & $6.5(2.2) \mathrm{Aa}$ & $4.4(1.7) \mathrm{Aa}$ & 19.6 (1.9) Аа & $14.9(1.5)$ & $\mathrm{Ab}$ \\
\hline $15 \% \mathrm{CP}$ & 61.3 (3.8) Aa & 69.1 (3.1) Ab & $8.0(1.7) \mathrm{Aa}$ & $4.2(1.3) \mathrm{ABb}$ & $17.4(1.6) \mathrm{Aa}$ & $13.1(2.1)$ & $\mathrm{Ab}$ \\
\hline $20 \%$ CP & 65.3 (3.6) $\mathrm{Aa}$ & 72.1 (2.6) Ab & $5.9(1.7) \mathrm{Aa}$ & $3.0(1.2) \mathrm{Bb}$ & 17.8 (1.8) Аa & $13.8(1.6)$ & $\mathrm{Ab}$ \\
\hline
\end{tabular}

Means followed by distinct letters differ statistically at 5\%, according to one-way repeated measures ANOVA and Tukey test ( $\alpha=0.05)$. Uppercase letters compare bleaching; lowercase letters compare time After treatment: $8 \mathrm{~h}$ of bleaching.

Table 4. Color alteration $(\Delta \mathrm{E})$ and whiteness index $(\Delta \mathrm{WI})$ mean values (standard deviation) according to the bleaching agents at different time points.

\begin{tabular}{llllllll}
\hline Group & $2 \mathrm{~h}-$ Baseline & $4 \mathrm{~h}-2 \mathrm{~h}$ & $6 \mathrm{~h}-4 \mathrm{~h}$ & $8 \mathrm{~h}-6 \mathrm{~h}$ & $8 \mathrm{~h}-$ Baseline & $\Delta \mathrm{WI}$ \\
\hline $6 \% \mathrm{HP}$ & $4.5(0.4) \mathrm{A}$ & $4.9(1.3) \mathrm{AB}$ & $5.7(1.2) \mathrm{AB}$ & $7.3(1.1) \mathrm{AB}$ & $9.3(2.2) \mathrm{AB}$ & $12.3(3.6) \mathrm{A}$ \\
$10 \% \mathrm{CP}$ & $3.3(0.8) \mathrm{A}$ & $3.7(2.2) \mathrm{B}$ & $4.8(2.1) \mathrm{B}$ & $5.3(3.2) \mathrm{B}$ & $7.8(2.1)$ & $\mathrm{B}$ & $14.0(6.0) \mathrm{A}$ \\
$15 \% \mathrm{CP}$ & $3.8(0,6) \mathrm{A}$ & $4.4(0.9) \mathrm{AB}$ & $6.7(2.5) \mathrm{A}$ & $8.4(2.5) \mathrm{A}$ & $11.5(1.8) \mathrm{A}$ & $17.6(4.4) \mathrm{A}$ \\
$20 \% \mathrm{CP}$ & $4.9(0.7) \mathrm{A}$ & $5.5(2.7) \mathrm{A}$ & $6.9(2.9) \mathrm{A}$ & $8.8(2.3) \mathrm{A}$ & $13.8(2.1) \mathrm{A}$ & $14.6(7.1) \mathrm{A}$ \\
\hline
\end{tabular}

Means followed by distinct letters comparing differ statistically at 5\% according to one-way ANOVA and Tukey test ( $\alpha=0.05)$. Uppercase letters compare bleaching treatment. 
followed by HP Maxx (5.1 - 6.0) and PO, which had the lowest $\mathrm{pH}$ values $(2.6-3.7)$ among the groups $(\mathrm{p}<0.0001)$. After 5 min of bleaching, the $\mathrm{pH}$ of $\mathrm{PO}$ laser increased from 2.6 to 3.1 and reach the $\mathrm{pH}$ of 3.5. Figure 6 displays $\mathrm{pH}$ variations of the high-concentrated agents as a function of time and light activation methods.

\section{Discussion}

The agents 6\% HP, 15\% CP, and 20\% CP exhibited significant decomposition at the beginning of the bleaching therapy (after $2 \mathrm{~h}$ ), whereas the decomposition rate of the 10\% CP agent decreased only after $4 \mathrm{~h}$ of bleaching. This might indicate that the agents with the lowest HP concentration present a more time-consuming decomposition rate than the most concentrated ones. In fact, this could be observed in the color alteration $(\Delta \mathrm{E})$ results, which are a consequence of the HP decomposition.

Table 5. $\mathrm{L}^{*}, \mathrm{a}^{*}, \mathrm{~b}^{*}$ mean values (standard deviation) according to the bleaching agents and light activation

\begin{tabular}{|c|c|c|c|c|c|c|c|c|c|c|c|c|c|c|c|c|c|c|c|}
\hline \multirow{3}{*}{ 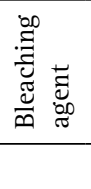 } & \multirow{3}{*}{$\begin{array}{c}\text { Group } \\
\text { Control }\end{array}$} & \multicolumn{6}{|c|}{$L^{*}$} & \multicolumn{6}{|c|}{$a^{*}$} & \multicolumn{6}{|c|}{$\mathrm{b}^{*}$} \\
\hline & & \multicolumn{3}{|c|}{ Baseline } & \multicolumn{3}{|c|}{ After treatment } & \multicolumn{3}{|c|}{ Baseline } & \multicolumn{3}{|c|}{ After treatment } & \multicolumn{3}{|c|}{ Baseline } & \multicolumn{3}{|c|}{ After treatment } \\
\hline & & 62.2 & (3.8) & $\mathrm{Aa}$ & 79.6 & (3.5) & $\mathrm{Aa}^{*}$ & 6.8 & $(0.9)$ & $\mathrm{Aa}$ & 4.7 & (1.3) & $\mathrm{Aa}^{*}$ & 19.5 & (2.3) & $\mathrm{Aa}$ & 13.5 & (2.6) & $\mathrm{Aa}^{*}$ \\
\hline \multirow{4}{*}{ 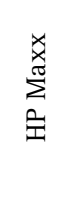 } & Led & 62.4 & $(2.3)$ & $\mathrm{Aa}$ & 80.6 & (2.7) & $\mathrm{Aa}^{*}$ & 5.2 & $(1.8)$ & $\mathrm{Aa}$ & 1.5 & $(0.8)$ & $\mathrm{Ba}^{*}$ & 19.3 & (1.9) & $\mathrm{Aa}$ & 9.4 & $(1.0)$ & $\mathrm{Bb}^{*}$ \\
\hline & Laser & 61.3 & (3.8) & $\mathrm{Aa}$ & 80.8 & (2.5) & $\mathrm{Aa}^{*}$ & 5.8 & $(0.9)$ & $\mathrm{Aa}$ & 2.0 & (1.3) & $\mathrm{Ba}^{*}$ & 17.4 & $(1.6)$ & $\mathrm{Aa}$ & 10.6 & $(2.4)$ & $\mathrm{Ba}^{*}$ \\
\hline & Halogen & 59.0 & $(1.9)$ & $\mathrm{Aa}$ & 78.9 & (1.9) & $\mathrm{Aa}^{*}$ & 5.9 & (1.8) & $\mathrm{Ab}$ & 3.1 & $(0.6)$ & $\mathrm{AB}^{*}$ & 17.8 & (1.8) & $\mathrm{Aa}$ & 8.9 & $(1.0)$ & $\mathrm{Ba}^{*}$ \\
\hline & Control & 58.8 & (5.1) & $\mathrm{Aa}$ & 76.2 & (3.1) & $\mathrm{Ab}^{*}$ & 6.4 & $(1.2)$ & $\mathrm{Ab}$ & 2.7 & (1.4) & $\mathrm{Ab}^{*}$ & 19.0 & $(1.1)$ & $\mathrm{Aa}$ & 9.9 & (1.9) & $\mathrm{Ab}^{*}$ \\
\hline \multirow{6}{*}{ 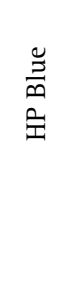 } & Led & 60.0 & $(3.0)$ & $\mathrm{Aa}$ & 76.3 & (4.3) & $\mathrm{Ab}^{*}$ & 6.6 & $(1.7)$ & $\mathrm{Aa}$ & 1.5 & $(0.5)$ & $\mathrm{Aa}^{*}$ & 19.6 & $(2.0)$ & $\mathrm{Aa}$ & 12.2 & $(1.5)$ & $\mathrm{Aa}^{*}$ \\
\hline & Laser & 62.8 & (3.6) & $\mathrm{Aa}$ & 74.4 & (1.9) & $\mathrm{Ab}^{*}$ & 6.3 & (1.4) & $\mathrm{Aa}$ & 2.9 & $(0.8)$ & $\mathrm{Aa}^{*}$ & 17.5 & (3.8) & Aa & 9.7 & $(0.9)$ & $A a^{*}$ \\
\hline & Halogen & 62.5 & $(4.1)$ & $\mathrm{Aa}$ & 78.5 & (4.3) & $\mathrm{Aa}^{*}$ & 5.3 & $(1.1)$ & $\mathrm{Ab}$ & 2.2 & $(0.8)$ & $\mathrm{Ab}^{*}$ & 18.2 & (1.5) & $\mathrm{Aa}$ & 9.8 & $(1.2)$ & $\mathrm{Aa}^{*}$ \\
\hline & Control & 62.8 & (1.8) & $\mathrm{Aa}$ & 78.2 & (3.3) & $\mathrm{Aa}$ & 4.6 & (1.4) & $\mathrm{Ab}$ & 1.9 & $(0.8)$ & $\mathrm{Ab}^{*}$ & 17.8 & (1.8) & $\mathrm{Aa}$ & 9.5 & (1.9) & $\mathrm{Ab}^{*}$ \\
\hline & Led & 62.1 & (2.5) & $\mathrm{Aa}$ & 77.6 & (3.6) & $\mathrm{Aa}^{*}$ & 6.0 & $(2.0)$ & $\mathrm{Aa}$ & 2.0 & $(0.5)$ & $\mathrm{Aa}^{*}$ & 17.9 & $(1.1)$ & $\mathrm{Aa}$ & 8.9 & (1.3) & $\mathrm{Ab}^{*}$ \\
\hline & Laser & 61.5 & (3.0) & $\mathrm{Aa}$ & 77.9 & (3.4) & $\mathrm{Aa}^{*}$ & 7.0 & (1.4) & $\mathrm{Aa}$ & 3.3 & (1.3) & $\mathrm{Aa}^{*}$ & 17.8 & (1.4) & $\mathrm{Aa}$ & 8.9 & $(0.6)$ & $\mathrm{Aa}^{*}$ \\
\hline 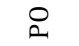 & Halogen & 60.1 & $(2.0)$ & $\mathrm{Aa}$ & 75.6 & (2.4) & $\mathrm{Ab}^{*}$ & 7.5 & (1.5) & $\mathrm{Aa}$ & 3.9 & $(2.0)$ & $\mathrm{Aa}^{*}$ & 19.2 & (1.9) & $\mathrm{Aa}$ & 9.9 & (1.8) & $\mathrm{Aa}^{*}$ \\
\hline
\end{tabular}

Means followed by distinct letters differ statistically at 5\%, according to two-way repeated measures ANOVA and Tukey test ( $\alpha=0.05)$.Uppercase letters compare lights for the same bleaching condition and time; lowercase letters compare bleaching agents for the same light condition and time. *Indicate differences between baseline and after treatment. After treatment: 40 min of bleaching.

Table 6. Color alteration $(\Delta \mathrm{E})$ and whiteness index $(\Delta \mathrm{WI})$ mean values (standard deviation) according to the bleaching agents and light activation.

\begin{tabular}{|c|c|c|c|c|c|c|c|c|c|c|c|c|c|c|}
\hline \multirow{3}{*}{ Group } & \multicolumn{13}{|c|}{$\Delta \mathrm{E}$} & \multirow{3}{*}{$\begin{array}{c}\Delta \mathrm{WI} \\
.6(8.4) \mathrm{Aa}\end{array}$} \\
\hline & \multicolumn{3}{|c|}{5 min - Baseline } & \multicolumn{2}{|c|}{$10 \min -5 \min$} & \multicolumn{2}{|c|}{20 min -10 min } & \multicolumn{2}{|c|}{30 min- 20 min } & \multicolumn{2}{|c|}{$40 \min -30 \min$} & \multicolumn{2}{|c|}{$\begin{array}{l}40 \text { min - } \\
\text { Baseline }\end{array}$} & \\
\hline & C & $7.0(0.2)$ & $\mathrm{Aa}$ & $8.0(0.3)$ & $\mathrm{Aa}$ & $10.1(0.1)$ & Aa & $10.6(0.3)$ & $\mathrm{Bb}$ & $10.2(0.2)$ & $\mathrm{Cb}$ & $19.3(3.6)$ & $\mathrm{Ab}$ & \\
\hline \multirow{4}{*}{$\begin{array}{l}\text { HP } \\
\text { Maxx }\end{array}$} & LED & $11.0(0.4)$ & $\mathrm{Aa}$ & $11.5(0.4)$ & $\mathrm{Aa}$ & $15.7(0.3)$ & $\mathrm{Ba}$ & $19.2(0.3)$ & Aa & $21.0(0.3)$ & $\mathrm{Ab}$ & 20.7 (3.7) & $\mathrm{Ab}$ & $24.8(2.7) \mathrm{Aa}$ \\
\hline & Laser & $8.2(0.5)$ & $\mathrm{Ab}$ & $8.9(0.5)$ & $\mathrm{Ab}$ & $13.4(0.3)$ & $\mathrm{ABb}$ & $14.2(0.7)$ & $\mathrm{ABb}$ & $15.7(0.3)$ & $\mathrm{Bb}$ & $20.9(4.9)$ & $\mathrm{Aa}$ & $22.5(3.7) \mathrm{Aa}$ \\
\hline & Hal & $10.0(0.2)$ & Аа & $10.3(0.4)$ & $\mathrm{Aa}$ & $12.5(0.4)$ & $\mathrm{Ab}$ & $15.9(0.5)$ & $\mathrm{ABb}$ & $16.4(0.3)$ & $\mathrm{Bb}$ & $21.9(2.4)$ & $\mathrm{Aa}$ & $22.4(2.9) \mathrm{Aa}$ \\
\hline & $\mathrm{C}$ & $9.6(0.4)$ & $\mathrm{Aa}$ & $10.2(0.5)$ & $\mathrm{Aa}$ & $15.5(0.6)$ & $\mathrm{Aa}$ & $19.2(0.4)$ & $\mathrm{Aa}$ & $22.3(0.4)$ & $\mathrm{Aa}$ & $22.3(5.6)$ & $\mathrm{Ab}$ & $27.5(4.5) \mathrm{Aa}$ \\
\hline \multirow{4}{*}{$\begin{array}{l}\text { HP } \\
\text { Blue }\end{array}$} & LED & $8.9(0.3)$ & $\mathrm{Ab}$ & $9.3(0.3)$ & $\mathrm{Ab}$ & $15.6(0.2)$ & Aa & $16.7(0.5)$ & $\mathrm{Ab}$ & $18.7(0.7)$ & $\mathrm{Ba}$ & $21.1(3.8)$ & $\mathrm{Ab}$ & $28.4(2.8) \mathrm{Aa}$ \\
\hline & Laser & $9.8(0.5)$ & $\mathrm{Ab}$ & $10.0(0.3)$ & $\mathrm{Aa}$ & $16.7(0.7)$ & $\mathrm{Aa}$ & $18.2(0.3)$ & Aa & $19.5(0.6)$ & $\mathrm{ABa}$ & $20.4(2.8)$ & $\mathrm{Aa}$ & $22.6(5.9) \mathrm{Aa}$ \\
\hline & Hal & $10.2(0.2)$ & Aa & $11.0(0.6)$ & $\mathrm{Aa}$ & $17.9(0.6)$ & $\mathrm{Aa}$ & $18.6(0.5)$ & $\mathrm{Aa}$ & $18.2(0.4)$ & $\mathrm{Ba}$ & $22.8(3.9)$ & $\mathrm{Aa}$ & $24.7(6.1) \mathrm{Aa}$ \\
\hline & C & $10.9(0.3)$ & $\mathrm{Aa}$ & $10.7(0.5)$ & $\mathrm{Aa}$ & $17.4(0.1)$ & $\mathrm{Aa}$ & $19.7(0.4)$ & Aa & $19.2(0.4)$ & $\mathrm{Ba}$ & 24.9 (2.6) & $\mathrm{Aa}$ & $23.3(3.3) \mathrm{Aa}$ \\
\hline \multirow{3}{*}{$\begin{array}{l}\text { Pola } \\
\text { Office }\end{array}$} & LED & $7.0(0.5)$ & $\mathrm{Ab}$ & $7.8(0.2)$ & $\mathrm{Ab}$ & $15.5(0.6)$ & $\mathrm{Aa}$ & $18.7(0.5)$ & $\mathrm{Aa}$ & $22.7(0.4)$ & $\mathrm{Ab}$ & $23.9(0.2)$ & $\mathrm{Aa}$ & $27.1(5.7) \mathrm{Aa}$ \\
\hline & Laser & $11.2(0.6)$ & $\mathrm{Aa}$ & $12.1(0.3)$ & $\mathrm{Aa}$ & $17.7(0.3)$ & Aa & $17.5(0.4)$ & Aa & $20.9(0.5)$ & Aba & $20.7(0.3)$ & $\mathrm{Aa}$ & $26.7(4.2) \mathrm{Aa}$ \\
\hline & Hal & $10.7(0.4)$ & $\mathrm{Aa}$ & $11.2(0.4)$ & $\mathrm{Aa}$ & $17.4(0.5)$ & $\mathrm{Aa}$ & $19.1(0.9)$ & Aa & $22.3(0.3)$ & $\mathrm{Aa}$ & $22.6(0.3)$ & $\mathrm{Aa}$ & $26.8(6.6) \mathrm{Aa}$ \\
\hline
\end{tabular}

Means followed by distinct letters differ statistically at 5\%, according to two-way ANOVA and Tukey Test ( $\alpha=0.05)$. Uppercase letters compare lights for the same bleaching condition; lowercase letters compare bleaching agents for the same light conditions. After treatment: 40 min of bleaching 
The $\Delta \mathrm{E}$ values of $20 \% \mathrm{CP}$ (at the time points $4 \mathrm{~h}-2 \mathrm{~h}$, $6 \mathrm{~h}-4 \mathrm{~h}, 8 \mathrm{~h}-6 \mathrm{~h}$ and $8 \mathrm{~h}$ - Baseline) were greater than that of $10 \% \mathrm{CP}(\mathrm{p}<0.05)$ and similar to $6 \% \mathrm{HP}$ and $15 \%$ exhibited increase in luminosity $\left(L^{*}\right)$, decrease in the yellow appearance of enamel $\left(b^{*}\right)$ and exceeded the value for clinical color perception ( $\Delta E>3.7)$ (19). The whiteness index used (WI) was specifically formulated for Dentistry and is a simple linear formulation using the three CIELAB chromatic coordinates $\left(L^{*}, a^{*}, b^{*}\right)$, aiming to avoid subjective visual factor in the dental color analysis (18). According indicate higher whiteness values. Low or even negative values disclose lower values of whiteness of the sample (18). In this study, only positive values were found for the low and high-concentrated agents, which indicated that even one bleaching application was able to whiten the black tea-stained enamel surface.

A single eight-hour application of 10\% CP promoted lower $\triangle \mathrm{E}$ compared to $15 \%$ and $20 \% \mathrm{CP}$ groups (Table 4). Contrary to these findings, Delfino, et al. (20) observed that color changes promoted by $16 \% \mathrm{CP}$ were similar to those of $10 \% \mathrm{CP}$ and this agent exhibited $\Delta \mathrm{E}$ values superior to the $6.5 \% \mathrm{HP}$ bleaching strips. However, the authors evaluated

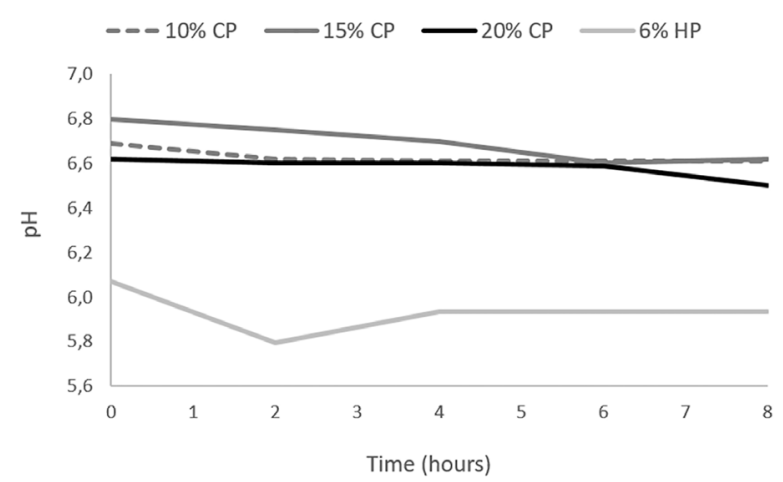

Fig. $5 \mathrm{pH}$ analysis of 10\% CP, 15\% CP, 20\% CP, and 6\% HP as a function of time. CP. However, it should be noted that after $8 \mathrm{~h}$, all groups to this method, the high positive values of the WI index

color after 7, 14, and 21 days of bleaching instead of the eight-hour decomposition rate/ $\Delta \mathrm{E}$ follow up, as this study aimed to evaluate. In a clinical trial, Cardoso, et al. (12) evaluated the effectiveness promoted by $10 \% \mathrm{CP}$ used for $15,30 \mathrm{~min}, 1 \mathrm{~h}$ and $8 \mathrm{~h} /$ day for 16 days. Patients who experienced bleaching for $8 \mathrm{~h} /$ day exhibited a slightly faster bleaching result than patients that bleached for $1 \mathrm{~h} /$ day, but both application times were considered satisfactory (12). According to these authors $(12,20), 10 \%$ CP could be recommended for lower application times and lower frequency (14 days) (20).

The CP agents $(10 \%, 15 \%$, and $20 \%)$ presented $\mathrm{pH}$ values close to neutral (6.5-6.9), whereas 6\% HP displayed lower $\mathrm{pH}$ values (6.1 - 5.9, from the beginning to the end of the bleaching treatment). Although $6 \% \mathrm{HP}$ is not below the critical $5.5 \mathrm{pH}$ value to promote enamel mineral loss (21), according to manufacturer's it should be used for $90 \mathrm{~min} /$ day.

These findings provide background to reject the first null hypothesis and suggest a protocol change for the low-concentrated bleaching therapy based on the decomposition rate, color change and $\mathrm{pH}$ of the bleaching agents. Instead of $8 \mathrm{~h}$ of bleaching, 10\% CP agent can be used for $4 \mathrm{~h}$ and $6 \% \mathrm{HP}, 15 \% \mathrm{CP}$, and 20\% CP agents can be used for up to $2 \mathrm{~h}$, but the bleaching therapy is extended for up to 14 days (12). Amongst the bleaching agents, we recommend the lowest concentrated agent $(10 \% \mathrm{CP})$ for home applications, in order to prevent possible cytotoxicity effects and lower sensitivity (22).

Some manufacturers of high-concentrated HP agents for in-office application indicate light activation (LED, Laser, or halogen lamp), with the purpose to increase the efficacy and accelerate decomposition rate of the agent, based on the thermocatalytic theory of HP decomposition (23). This theory supports the idea that the production of hydroxyl radicals is hastened by temperature increase and therefore, when light energy reaches the bleaching agent, a fraction of this energy is absorbed and converted into heat. In order to increase light absorption, some agents contain a specific photosynthetic pigment such as carotene. This agent has a reddish color and increases blue light absorption. Another method used by manufacturers to increase light absorption is the addition of nanometer silica particles, which provides the blue color to the bleaching agents (23).

The decomposition of

Fig. $6 \mathrm{pH}$ analysis of 35\% HP agents as a function of time and light activation method.

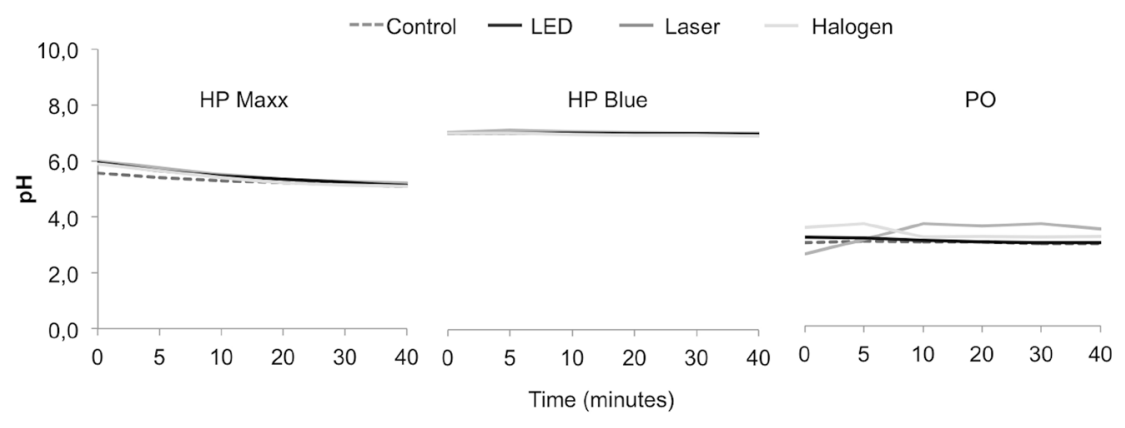

HP Maxx began 5 min after 
application, irrespective of light activation and after 40 min, no differences were observed among HP Maxx groups, regardless light activation. Similar to these results, Hein et al. reported that the application of light and heat were unable to increase the decomposition rate of HP (24). However, these authors observed that carotene-containing agents considerably increased the temperature of these agents, which is a concern for pulp safety and pulp damage $(23,24)$. According to manufacturer's directions, HP Maxx could have a better performance when light-activated; however, based on the decomposition rate results, HP Maxx directions could change, as no differences were noted among groups regardless of light activation. In addition, it must be pointed out that HP Maxx is a pigment-containing agent and the possibility of a temperature rise reaffirms that there is no need for light activation.

Contrarily, HP Blue was influenced by the light activation method as LED, laser and halogen lamp decrease the HP DR after 5, 10 and 20 min, respectively, while $C$ decreased only after 30 min of bleaching. In a previous study, it was observed that LED or laser irradiation increased the final concentration of 35\% HP in the pulp chamber (8), which might indicate a higher decomposition rate when the agent is light activated. However, after $40 \mathrm{~min}$, HP Blue LED and halogen exhibited lower HP rates than laser-activated group, but all groups were similar to $\mathrm{C}$. Since no differences were observed between $C$ and the light-activated groups, we support the manufacturer's recommendation, as no light sources is needed to accelerate bleaching. Moreover, although $\mathrm{PO}$ was accelerated by LED and laser sources after 5 min of bleaching, after $10 \mathrm{~min}, \mathrm{C}$ group lower the HP rate. Therefore, we upkeep PO directions that state that the product can be used without light activation. Based on these results, we reject the second null hypothesis as decomposition rate is influenced by light sources; however, we do not indicate the use of light, as no differences could be observed among light- and non-activated groups at the end of bleaching.

The manufacturers of most in-office bleaching agents indicate three applications of 15 min each. In the current study, the authors observed that one single application of 40 min promotes approximately 15\% of the decomposition rate, and most groups reached a final averaged concentration of 20\% HP. These results are comparable to those of Marson et al. (17), in which the authors observed that the decomposition rate of $38 \% \mathrm{HP}$ and 35\% HP agents reached 29-33\% in one single 45-min application. The authors concluded that there is no need to remove the agent after $15 \mathrm{~min}$ and repeat the application, as long as $\mathrm{pH}$ is kept neutral (17).

Changes in the protocol of high-concentrated bleaching agents have recently been suggested (13). That investigation compared different concentrations of HP $(17.5 \%$, $35 \%$, or $37 \%$ ) with distinct application protocols ( 1 or 3 applications for $5 / 15$ min or 10/20 min for the $37 \% \mathrm{HP}$ ) and concluded that all procedures effectively changed the tooth color, but shortening the contact time or reducing the concentration of the 35\% HP gel decreases enamel-dentin diffusion. Therefore, the reduction in the frequency of the application (from 3 to 1 time in one single session) could decrease the amount of product reaching the pulp chamber and the possible side effects promoted by HP in pulp cells, as the amount of HP that diffuses through enamel and dentin is directly related to the toxic effects to cells (13).

Although some differences were observed in the decomposition rate among groups, all of them were able to change enamel color after 40 min of bleaching, even in one single application. It is important to observe that $\Delta \mathrm{E}$ obtained by all the groups exceeded the value for clinical color perception ( $\Delta E>3.7$ ) (19). Therefore, decrease the application time and frequency of in-office agents without light activation seems to be an effective and possibly safe option, as HP diffusion could be diminished.

Among the high-concentrated agents, HP Blue presented high $\mathrm{pH}$ values (approximately 8.0, from the beginning to the end of bleaching), but HP Maxx and $\mathrm{PO}$ exhibited $\mathrm{pH}$ values below the critical $\mathrm{pH}$ value for enamel (mean values of 5.0 and 3.0, respectively). These $\mathrm{pH}$ values are a warning that in-office bleaching treatment should be carefully indicated due to the potential enamel mineral loss triggered by bleaching (24), especially with the high frequency of applications (13). For that reason, PO manufacturer's directions to apply the agent for 8 to $20 \mathrm{~min}$ is consistent with our findings and HP Blue could be used for up to $40 \mathrm{~min}$; however, preferably both agents in one single application. On the other hand, HP Maxx directions could be reduced to one single 15-20 min application, due to the low $\mathrm{pH}$, decomposition rate and color alteration behavior. Therefore, the third null hypothesis could also be rejected as high-concentrated agents could be applied once for up to 20 (PO and HP Maxx) or 40 min (HP Blue).

Since this is an in vitro assessment, it must be kept in mind that saliva would clinically balance enamel mineral loss (21), but the quality of the surface on which the bleaching agent is applied (enamel with minor fissures or cervical dentin expositions) is an important factor to consider since this could also increase HP diffusion and bleaching sensitivity (13). Future clinical studies should be conducted to assess whether the reduced application time would be able to reach the desired color change and decrease the possibility of tooth sensitivity.

In conclusion, the application mode of in-office and athome bleaching agents suggested by manufacturers could 
decrease without compromising bleaching effectiveness, particularly those with low $\mathrm{pH}$.

\section{Resumo}

Este estudo avaliou a taxa de decomposição (DR), pH, alteração da cor do esmalte $(\Delta \mathrm{E})$ e indice de clareamento $(\Delta \mathrm{WI})$ promovido por agentes clareadores caseiros e de consultório. A superfície do esmalte foi submetida a $(n=10)$ : agentes caseiros $(10 \%, 15 \%, 20 \%$ de peróxido de carbamida - CP e 6\% de peróxido de hidrogênio - HP) e três agentes a base de HP a 35\% comirradiação por luz (LED, laser e halógena) ou sem tratamento (controle). A DR e pH dos agentes foi mensurada após $0,2,4,6$ e $8 \mathrm{~h}$ (agentes caseiros) e após 5, 15, 20, 30 e 40 min (agentes de consultório). Parâmetros de cor $\left(L^{*}, a^{*}, b^{*}, D E\right.$ e $\left.\Delta W I\right)$ foram determinados inicialmente e após clareamento. Os dados da $\mathrm{DR}, \mathrm{pH}, \mathrm{L}^{*}, \mathrm{a}^{*}, \mathrm{~b}^{*}$ foram analisados por ANOVA um fator (agentes caseiros) ou dois fatores (agentes de consultório) de medidas repetidas e teste Tukey. $\triangle \mathrm{E}$ e $\triangle \mathrm{WI}$ por ANOVA um fator (agentes caseiros) e dois fatores (agentes de consultório) e teste Tukey. A DR dos agentes clareadores caseiros foi similar após 6 e $8 \mathrm{~h}(\mathrm{p}>0.05)$, com pH próximo ao neutro (6,5 a 6,9 - CP) ou ácido (5,9- HP 6\%). De 4 a $8 \mathrm{~h}$, a $\Delta$ E foi maior para CP $15 \%$ e $20 \%$ comparado ao CP $10 \%(\mathrm{p}<0.05)$. Após $40 \mathrm{~min}$, a DR dos agentes HP $35 \%$ foi similar e todos exibiram $\Delta \mathrm{E}$ significante em uma aplicação $(p<0.05)$, independente da aplicação de luz. $\Delta W \mathrm{Wl}$ indicou efeito clareador, sem diferenças entre os grupos ( $p>0.05)$. Um agente HP $35 \%$ exibiu $\mathrm{pH}$ alcalino, e os outros, $\mathrm{pH}<5.5$. Os agentes clareadores caseiros poderiam ser aplicados por $2 \mathrm{~h}(15 \%, 20 \%$ CP e $6 \%$ $\mathrm{HP}$ ) e $4 \mathrm{~h}$ (CP 10\%), e os agentes clareadores de consultório, até $40 \mathrm{~min}$ em uma aplicação, sem luz.

\section{Acknowledgements}

This investigation was supported by Research Grants 2011/17507-5 from the State of São Paulo Research Foundation, FAPESP, São Paulo, Brazil.

References

1. Kina JF, Huck C, Riehl H, Martinez TC, Sacono NT, Ribeiro APD, et al. Response of human pulps after professionally applied vital tooth bleaching. Int Endod J 2010;43:572-580.

2. Gökay O, Yilmaz F, Akin S, Tunçbilek M, Ertan R. Penetration of the pulp chamber by bleaching agents in teeth restored with various restorative materials. J Endod 2000;26:92-94.

3. De Lima AF, Lessa FCR, Mancini MNG, Hebling J, De Souza Costa CA, Marchi GM. Cytotoxic effects of different concentrations of a carbamide peroxide bleaching gel on odontoblast-like cells MDPC-23. J Biomed Mater Res - Part B Appl Biomater 2009;90:907-912.

4. Soares DGS, Ribeiro APD, Sacono NT, Coldebella CR, Hebling J, De Souza Costa CA. Transenamel and transdentinal cytotoxicity of carbamide peroxide bleaching gels on odontoblast-like MDPC-23 cells. Int Endod J 2011;44:116-125.

5. Berger SB, Cavalli V, Martin AA, Soares LES, Arruda MAZ, Brancalion ML, et al. Effects of combined use of light irradiation and 35\% hydrogen peroxide for dental bleaching on human enamel mineral content. Photomed Laser Surg 2010;28:533-538.

6. Hanks $\mathrm{CT}$, Fat JC, Corcoran JF, Wataha JC. Cytotoxicity and dentin permeability of carbamide peroxide and hydrogen peroxide vital bleaching materials, in vitro. J Dent Res 1993;72:931-938.
7. Bowles WH, Ugwuneri Z. Pulp chamber penetration by hydrogen peroxide following vital bleaching procedures. J Endod 1987;13:375377.

8. Camargo $\mathrm{SE}$, Cardoso $\mathrm{PE}$, Valera $\mathrm{MC}$, de Araújo $\mathrm{MA}$, Kojima $\mathrm{AN}$. Penetration of $35 \%$ hydrogen peroxide into the pulp chamber in bovine teeth after LED or Nd:YAG laser activation. Eur J Esthet Dent 2009;4:82-88

9. Camargo SEA, Valera MC, Camargo CHR, Gasparoto Mancini MN, Menezes MM. Penetration of 38\% Hydrogen Peroxide into the Pulp Chamber in Bovine and Human Teeth Submitted to Office Bleach Technique. J Endod 2007;33:1074-1077.

10. Gökay 0, Müjdeci A, Algin E. In vitro peroxide penetration into the pulp chamber from newer bleaching products. Int Endod J 2005;38:516-520.

11. Haywood VB. History, safety, and effectiveness of current bleaching techniques and applications of the nightguard vital bleaching technique. Quintessence Int. 1992;23:471-488.

12. Cardoso PC, Reis A, Loguercio A, Vieira LCC, Baratieri LM. Clinical effectiveness and tooth sensitivity associated with different bleaching times for a 10 percent carbamide peroxide gel. J Am Dent Assoc 2010;141:1213-1220

13. Soares DG, Basso FG, Pontes EC V, Garcia LDFR, Hebling J, De Souza Costa CA. Effective tooth-bleaching protocols capable of reducing $\mathrm{H}_{2} \mathrm{O}_{2}$ diffusion through enamel and dentine. J Dent 2014;42:351-359.

14. Mondelli RF, Soares AF, Pangrazio EG, Wang L, Ishikiriama SK, Bombonatti JF. Evaluation of temperature increase during in-office bleaching. J Appl Oral Sci 2016;24:136-141.

15. Mondelli R, Rizzante $F$, Rosa ER, Borges A, Furuse AY, Bombonatti J. Effectiviness of LED/Laser irradiation on in-office dental bleaching after three years. Oper Dent 2018;43:31-37.

16. Sulieman $M$, Addy $M$, Rees JS. Development and evaluation of a method in vitro to study the effectiveness of tooth bleaching. J Dent 2003:31:415-422

17. Marson F, Gonçalves R, Silva C, Cintra L, Pascotto R, Santos P dos, et al. Penetration of hydrogen peroxide and degradation rate of different bleaching products. Oper Dent 2015;40:72-79.

18. Pérez M del M, Ghinea R, Rivas MJ, Yebra A, lonescu AM, Paravina RD, et al. Development of a customized whiteness index for dentistry based on CIELAB color space. Dent Mater 2016;32:461-467.

19. Johnston WM. Color measurement in dentistry. J Dent. 2009;37:e2-6.

20. Delfino CS, Chinelatti MA, Carrasco-Guerisoli LD, Batista AR, Fröner IC, Palma-Dibb RG. Effectiveness of home bleaching agents in discolored teeth and influence on enamel microhardness. J Appl Oral Sci 2009;17:284-288.

21. Margolis HC, Zhang YR, Lee CY, Kent RL, Moreno EC. Kinetics of enamel demineralization in vitro. J Dent Res 1999:78:1326-1335

22. Coldebella CR, Ribeiro APD, Sacono NT, Trindade FZ, Hebling J, Costa CA de S. Indirect cytotoxicity of a 35\% hydrogen peroxide bleaching gel on cultured odontoblast-like cells. Braz Dent J 2009;20:267-274.

23. Buchalla W, Attin T. External bleaching therapy with activation by heat, light or laser: A systematic review. Dent Mater 2007;23:586-96.

24. Hein D, Ploeger B, Hartup J, Wagstaff R, Palmer T, Hansen LD. In-office vital tooth bleaching - what do lights add? Compend Contin Educ Dent 2003:24:340-352. 
Braz Dent J 30(4) 2019 
Braz Dent J 30(4) 2019 